\title{
Pemberdayaan Masyarakat Dalam Penganggulangan Tanah Longsor Di Dusun Sonyo
}

\author{
Iswanto', Guntur Nugroho², Muhammad Abdus Shomad³, Nia Maharani Raharja4, Alfian \\ Ma'arif5
}

1. Program Profesi Insinyur, Universitas Muhammadiyah Yogyakarta, Yogjakarta

2. Teknik Sipil, Universitas Muhammadiyah Yogyakarta, Yogjakarta

3 Teknik Mesin Otomotif dan Manufaktur, Universitas Muhammadiyah Yogyakarta, Yogjakarta

4 Teknik Informatika, Universitas Islam Negeri Sunan Kalijaga, Yogjakarta

5 Teknik Elektro, Universitas Ahmad Dahlan, Yogyakarta

Email: iswanto_te@umy.ac.id

DOI: $10.18196 / p p m .36 .326$

\begin{abstract}
Abstrak
Dukuh Sonyo dipimpin oleh Bapak Suranto sebagai kepala dukuh. Pedukuhan tersebut terdiri atas delapan RT dengan jumlah kepala keluarga adalah 173. Pedukuhan tersebut terletak di daerah pegunungan di Kabupaten Kulon Progo. Dukuh Sonyo berbatasan dengan Dukuh Sidomulyo dan Dukuh Gunung Kelir. Pedukuhan Sonyo yang terletak di daerah pegunungan memiliki banyak permasalahan. Salah satu permasalah yang menjadi perhatian khusus yaitu permasalahan tentang rawannya terjadi bencana alam. Bencana alam yang sering terjadi di dusun tersebut yaitu tanah longsor. Dikhawatirkan pada musim hujan disertai terjadi hujan lebat dapat mengakibatkan tanah longsor. Berdasarkan permasalahan di atas maka pengabdian masyarakat ini mendesain dan menerapkan alat peringatan dini tanah longsor. Alat ini dibuat dengan menggunakan komponen utamanya mikrokontroller yang digunakan sebagai pengolah data, sensor menggunakan potensiometer untuk mendeteksi pergerakkan tanah, dan sirine. Selain pemasangan alat tanah longsor, pengabdian masyarakat ini juga memberikan pelajaran tentang pengangulangan tanah longsor
\end{abstract}

Kata Kunci: Early Warning System; Tanah longsor; Mikrokontroler; Dusun Sonyo

\section{Pendahuluan}

Dukuh Sonyo sendiri terdiri dari delapan RT dengan jumlah kepala keluarga adalah 173. Berdasarkan informasi yang didapatkan dari Bapak Suranto sebagai kepala dukuh, Pedukuhan Sonyo memiliki beberapa kelompok organisasi informal masyarakat seperti karang taruna dan ibu-ibu PKK. Dukuh Sonyo berbatasan dengan Dukuh Sidomulyo dan Dukuh Gunung Kelir. Penduduk Dukuh Sonyo mayoritas beragama Islam dan memiliki mata pencaharian sebagai buruh namun ada pula yang bekerja sebagai wiraswasta karena lokasi geografis Dukuh Sonyo terletak di dataran tinggi.

Daerah Dukuh Sonyo merupakan daerah pengunungan yang terletak di Kabupaten Kulon Progo. Daerah tersebut memiliki potensi rawan bencana alam. Saat musim hujan berlangsung, daerah Dukuh Sonyo sering mengalami bencana alam tanah longsor. Meskipun bencana alam ini tidak menimbulkan korban jiwa dan harta benda, bencana alam tersebut harus kita tanggulangi.

Permasalahan yang ada di dukuh Sonyo yang menjadi perhatian kami yaitu permasalahan tentang rawannya terjadi bencana alam, karena Dukuh Sonyo ini berada di lereng gunung dan banyak pohonpohon tinggi menjulang, dikhawatirkan pada musim hujan seperti sekarang ini terjadi hujan lebat yang disertai dengan angin kencang yang nantinya akan terjadi longsor atau bencana alam lainnya. Permasalahan yang terjadi di Dukuh Sonyo yaitu saat musim hujan terjadi, Dukuh Sonyo memiliki potensi rawan bencana tanah longsor

\section{Metode Pelaksanaan}

Rencana kegiatan dalam rangka melaksanakan program yang ditawarkan tersebut, secara rinci adalah:

1) Pembuatan Alat Peringatan Dini Tanah Longsor

Kegiatan ini bertujuan membuat alat deteksi tanah longsor. Pembuatan tersebut dilaksanakan di bengkel jurusan Teknik Elektro Universitas Muhammadiyah Yogyakarta dengan melibatkan beberapa mahasiswa dan teknisi.

2) Pemasangan 
Pemasangan deteksi tanah longsor ini di bantu oleh mahasiswa KKN dan dosen teknik sipil yang memiliki pengetahuan tentang tanah longsor. Selain memasang alat tersebut kami memberikan solusi untuk pencegahan tanah longsor.

\section{Hasil dan Pembahasan}

Program kegiatan pengabdian masyarakat ini melibatkan mitra yang berada di dusun Sonyo. Langkah pertama dalam progam ini adalah survei lokasi awal yang tujuannya adalah mengetahui permasalahan dan potensi yang ada di Desa Sonyo. Survei lokasi awal telah dilakukan pada tanggal 2 Januari 2020 serta diikuti oleh seluruh tim pengabdian, dan tim KKN UMY yang ditunjukkan pada Gambar 1 .

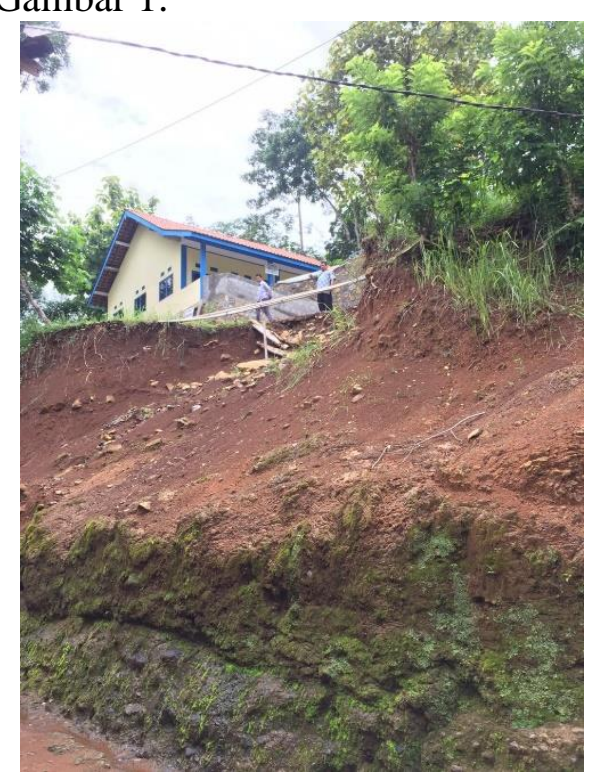

Gambar 1 Survei lokasi awal

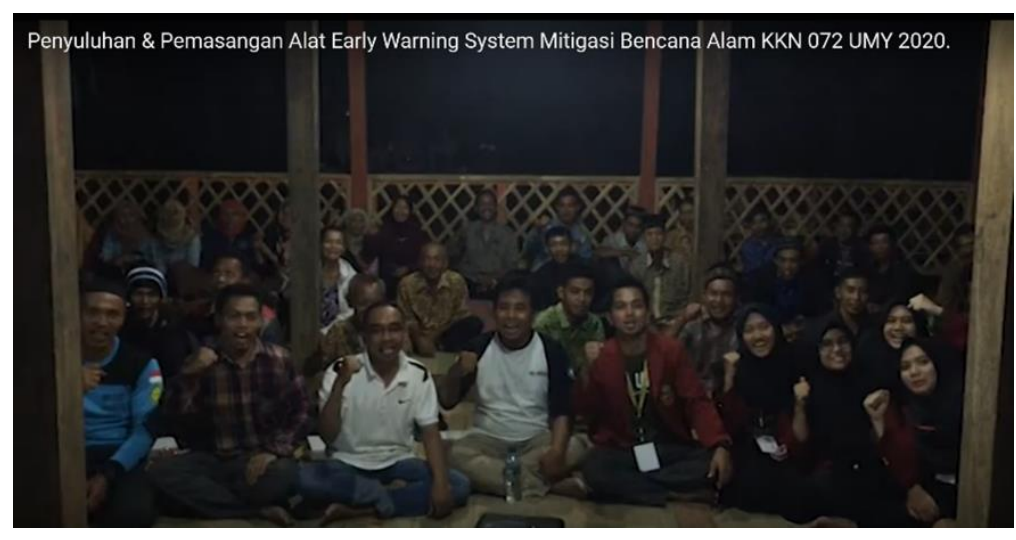

Gambar 2 Survei lokasi awal

Dari gambar tersebut terlihat bahwa Dusun Sonyo memiliki potensi bencana alam yang tinggi. Terlihat dari gambar tersebut terdapat tanah yang sudah longsor di daerah Sonyo. Setelah permasalahan sudah diketahui, langkah selanjutnya adalah melakukan koordinasi dengan mitra tentang sosialisasi bencana alam tanah longsor di Dusun Sonyo, Kecamatan Girimulyo, Kabupaten Kulon Progo

Pada koordinasi ini telah dicapai kesepakatan bersama untuk melaksanakan kegiatan pengabdian masyarakat sesuai dengan proses maupun waktu pelaksanaannya. Kesepakatan ini menjadi komitmen penting untuk suksesnya kegiatan pengabdian masyarakat dengan produk unggulan "pembuatan alat deteksi tanah longsor" Kabupaten Kulon Progo. Penyuluhan bahaya 
tanah longsor telah dilakukan pada tanggal 20 Januari 2020 serta diikuti oleh seluruh tim pengabdian, mitra, tim KKN UMY dan kepala desa ditunjukkan pada Gambar 2. Dari gambar tersebut, sosialisasi penyuluhan potensi bencana alam yang ada di Dusun Sonyo dihadiri oleh warga dan Kepala Dukuh Dusun Sonyo.

Setelah kegiatan sosialisasi, dilanjutkan dengan pemasangan perangkat pada tanggal 23 Januari 2020 serta diikuti oleh seluruh tim pengabdian, mitra, tim KKN UMY dan kepala desa. Pelaksanaan pemasangan alat deteksi tanah longsor pada Kelompok Mitra ditunjukkan pada Gambar 3

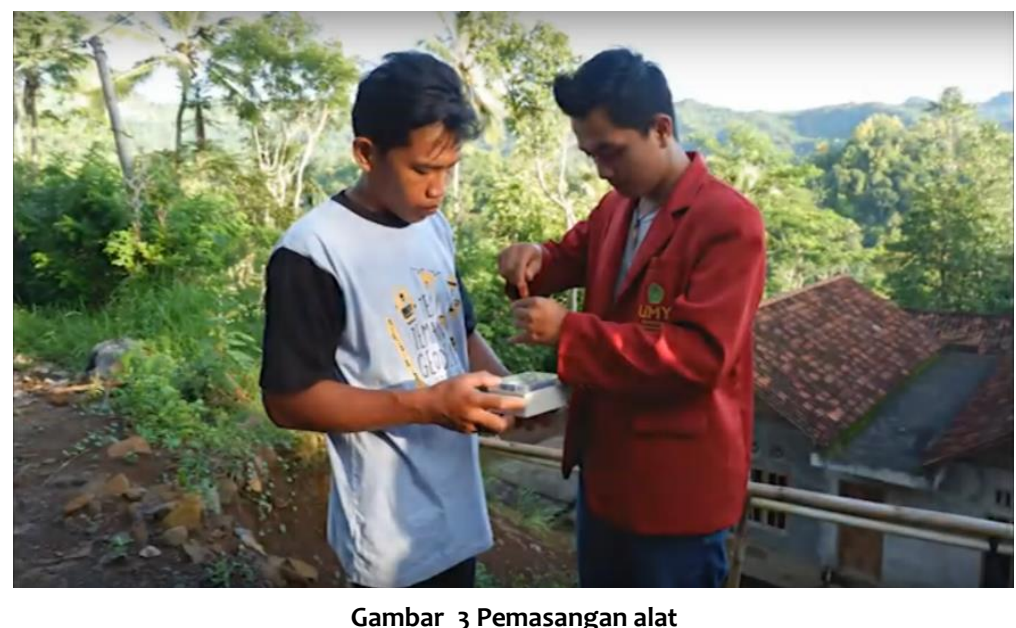

Kegiatan dalam penyuluhan dan sosialisasi pemasangan alat deteksi tanah longsor di Dusun Sonyo Kecamatan Girimulyo Kabupaten Kulonprogo ini telah dipublikasi dalam media massa. Kegiatan sosialisasi dan kegiatan pelatihan sudah dipublikasi oleh media massa di Tribun Jogja, Kamis Pon 27 Februari 2020.

\section{Simpulan}

Simpulan yang dapat diambil dari kegiatan PKM pemberdayaan masyarakat dalam penganggulangan Tanah Longsor di Dusun Sonyo sebagai berikut : (1) Survei lokasi awal telah dilakukan pada tanggal 2 Januari 2020 serta diikuti oleh seluruh tim pengabdian, dan tim KKN UMY yang ditunjukkan pada Gambar 1. (2) Koordinasi dengan mitra tentang sosialisasi bencana alam tanah longsor di Dusun Sonyo Kecamatan Girimulyo Kabupaten Kulon Progo. (3) Setelah kegiatan sosialisai dilanjutkan dengan pemasangan pada tanggal 23 Januari 2020 serta diikuti oleh seluruh tim pengabdian, mitra, tim KKN UMY, dan kepala desa. Pelaksanaan pemasangan alat deteksi tanah longsor pada Kelompok Mitra. Luaran kegiatan berupa alat deteksi tanah longsor. saran kegiatan selanjutnya adalah monitoring dan evaluasi keberlanjutan unit usaha bubuk kopi salak pondok, memastikan standar mutu produk dari kopi instan yang diproduksi, penyempurnaan kemasan, dan pelabelan produk serta memperluas jejaring pemasaran berbasis ritel.

\section{Ucapan Terima Kasih}

Ucapan terima kasih terutama kepada pemberi dana internal pengabdian masyarakan dengan nomor kontrak 031/PEN-LP3M/I/2020

\section{Daftar Pustaka}


Biro Pusat Statistik. 2000. Pengukuran dan Analisis Ekonomi Kinerja Penyerapan Tenaga Kerja.

Nilai Tambah, dan Eksport Usaha kecil Menengah serta peranannya terhadap Tenaga kerja Nasional dan Produk Domestik Bruto. Jakarta.

BPS. 2001. Profil Industri Kecil dan Kerajinan Rumah Tangga: Tahun 1999, Jakarta.

Jafar Hafsah. 2004. Upaya Pengembangan Usaha Kecil Dan Menengah (UKM). Infokop Nomor 25 Tahun XX.

Kenneth N. Wexley. 1991. Developing and Training Human Resources in Organizations.

Krisdianto, G. Sumarni dan A. Ismanto. 2000. Sari Hasil Penelitian Bambu. Pusat Penelitian Hasil Hutan. Bogor.

Kuncoro, M. 2002. Analisis Spasial dan Regional: Studi Aglomerasi dan Kluster Industri Indonesia. Yogyakarta: UPP-AMP YKPN

Noer Soetrisno. 2002. Pengembangan UKM, Ekonomi Rakyat Dan Penanggulangan Kemiskinan. Jakarta.

Raymond A. Noe. 1994. Employee Training and Development

Shujiro Urata Ph.D. 2000. Policy Recommendation for SME Promotion in the Republic of Indonesia, JICA Senior Advisor to Coordination Minister of Economy, Finance and Industri, Jakarta.

Sumardjo, 2004, Teori dan Praktik Kemitraan Agribisnis, Penerbit Penebar Swadaya, Jakarta.

Tambunan, T. 1999. Perkembangan Industri Skala Kecil Di Indonesia. Jakarta: PT. Mutiara

Sumber Widya. Tarsis Tarmudji. 1996. Prinsip-prinsip Wirausaha. Yogyakarta: Liberty.

Toha, M t.th. 1997. Permasalahan Industri Kecil Kotamadya Yogyakarta, Yogyakarta : IKIP Irats. 